\title{
Enriching Contents of Morality and Law Course
}

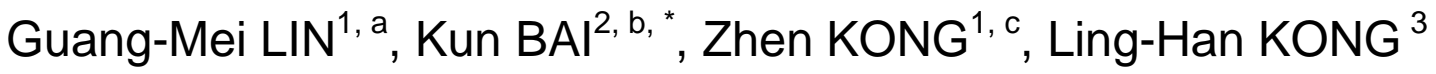 \\ ${ }^{1}$ Beijing Information Technology College, \\ No. 5, Fangyuanxilu, Chaoyang District, Beijing, China \\ ${ }^{2}$ University of International Relations, \\ No. 12, Poshangcun, Haidian District, Beijing, China \\ ${ }^{3}$ Beijing Bayi School, \\ No. 29, Suzhoujie, Haidian District, Beijing, China \\ aLingm@bitc.edu.cn, ${ }^{\mathrm{b}}$ Baikun@uir.edu.cn, ${ }^{\mathrm{C}}$ Kongz@bitc.edu.cn
}

Keywords: Students, Vocational college, Politics, Law.

\begin{abstract}
The paper discusses the necessity, the Contents and the realization approaches in the professional view education's integrating into the course of vocational colleges, aiming to strengthen students' conception as well as to improve the efficiency of teaching. Teaching model is one of the important ways to realize the goal of cultivating the high-quality talents. The improved teaching model research focuses on exploring the course of Morality and Law by deigning targets, paths, content, methods and evaluation ways, to enhance the efficiency and effect. Participative teaching provides a new teaching ideology and reform strategy for the curriculum Morality and Law Basis in vocational colleges. It can also fundamentally change the dissymmetry relationship between teaching and learning in the curriculum. It emphasizes respecting students' thought demand and mental feelings. In this way, students' cooperative awareness, communication skills and innovation capabilities as well as the teachers and other administrator's quality can be improved.
\end{abstract}

\section{Introduction}

Ideological and political theory courses are the main channel of the ideological and political construction which the CPC central committee has been very concerned about. Strengthening and improving ideological and political education of the guiding ideology, basic principles, basic requirements, main ways and methods is more and more important in the $13^{\text {th }}$ Five Year Plan. A series of documents have been published for the curriculum plan and deployment in the New Era. The course should be definitely what students really love, bringing lifelong benefit. The construction of theory courses should focus on how to improve the effective realization of the aims of vocational colleges as to train high-quality, highly skilled personnel.

\section{Enriching Teaching Contents}

Teaching materials of "Ideological and Moral Cultivation and Legal Basis" in vocational college reflects standardization of state-planned teaching. Facing this reality, creativity and flexibility should be advocated. Local cultural resources can enrich the content and refresh class activities, leading to a clearer target in an more efficient class. It is an important part of ideological theory courses and humanistic education system. Morality and law are the most basic codes of conduct which support the order of the human society. At the same time, they are the core content of the course. The problem is lacking in-depth analysis in current teaching materials about the significance to the human society. The research team thinks that morality constitute the core content of human being's spiritual life and verify human's transcendence in spiritual domain. The legal thoughts of social contract theory have many limitations, but it's an important supplement to legal thoughts about Marxism. The integration of local cultural resources and "Ideological and Moral Cultivation and Legal Basis" should follow the right political orientation, distinguish between primary and secondary, eliminate the false and retain the true so as to strengthen practical teaching. With 
declining cognitive ability of vocational college students, teachers really need a thorough reform to explain the theory, to arouse the interest in study. Bringing volunteer service into practical teaching of the course is a breakthrough to change the present loose relation between theoretical teaching and practice so as to promote the unity of knowledge and action and better realize the teaching aim of the course. This opinion is supported by theoretical basis and realistic conditions. The approaches and measures include: formulate integrated volunteer service practical teaching system; implement basic volunteer theoretical education in theory teaching process, organize and instruct volunteer service practice, assess volunteer service practical teaching activities and establish volunteer service practical teaching bases for university students, etc. In order to enhance the practicality of the course, teachers should strengthen the practical links. The practical teaching should be combined with theoretical teaching, filled with activities close to students' daily life. Although off-school practices are helpful for students' in-depth contact with the society, but they are usually broken from theoretical teaching, hard to organize and implement, and easily stay superficial. Practice inside the school, with its advantages of easy operation, low cost and quality guarantee, is short in students' learning the society. So practical education should take the mode of inside-school practice as main body, off-school practice as supplement, to improve the efficacy of the course. Six forms of inside-school practice could be used, such as reading after class, inside-school investigation, visiting, emotion experience, participation in teaching activities and etc.

\section{Teaching for Critical Thinking}

Understanding and thinking critically is a crucial skill in the modern world. Critical thinking is at the core of what we do, from essays and lists to models and teacher training. Conversation is a fundamental part of critical thinking, if for no other reason than the ability to identify a line of reasoning, analyze, evaluate, and respond to it accurately and thoughtfully is among the most common opportunities for critical thinking for students in every day life. Who is saying what? What's valid and what's not? How should I respond? Teachers need to help college students develop the skills and dispositions of a critical thinker. A perennial goal of college instruction is critical thinking, but until recently the actual research on these skills was limited. The best resources for critical thinking is an effective classroom. The college administrator should establish a classroom culture of conversation, providing models and suggested activities for cultivating classrooms that value learning through constructive conversation. A course consists of three online sessions, three weeks in a row. Each session includes expert video screen casts, classroom video clips, readings and resources, and assignments that will prompt participants to strengthen the curricular foundations of communication the first month of school. More efforts are needed to envision the conversational opportunities, and craft effective prompts for back and forth conversations between students. Teachers set up an assessment plan for assessing and reflecting on observations of paired student conversations, providing right-now feedback to students during their conversations, and reflect on conversation assessment to improve teaching and assessment. It represents the integration of legal philosophy with modern philosophical thought. It is also an attempt to find the necessary balance between the autonomous liberty of the individual, and the smooth evolution of social and political morality. It has made the philosophy of law more accessible and more meaningful. Students live in social settings which partially disclose this morality through their legal systems. Thus, law may be viewed as illuminating the foundation of morality. It is a resting place as well as a platform from which we are able to step to derivation and implication. The beginning of wisdom in the understanding and analysis of legal systems and legal concepts have been found in the lectures and writings.

\section{Providing Practical Instruction}

Practical instruction is an important part of the course. A systematic practical instruction system must be established to ensure effective implementation of the practical instruction activities. The establishment is a complicated engineering, which must be pushed forward on the basis of the 
construction of organization system, instruction implementation system as well as examination and evaluation system. Instruction involves much more than just talking to people; it requires posing intelligent questions that inspire the students to talk about their thoughts, their work and their concerns. Teachers can use a proactive process to help them upgrade their skills, reach their own solutions and understand their own actions. Weixin (an instant message communication tool) is a useful way to get students to ask questions, provide examples, respond to questions \& offer reactions to the class. It bypasses the dynamics of verbal participation, giving everyone an equal chance to speak. It provides anonymity - meaning nobody runs the risk of looking stupid. It allows students to ask questions as they occur to them - not only when the professor invites questions in class. It enhances the attraction and impressiveness of the subject as well as improve the teaching effect. And a practical approach of interactive teaching is presented, in which interactive teaching is implemented in class, out of class, in term and out of term synthetically between teachers and students so as to facilitate both teaching and study and improve the pertinence and effectiveness of this subject. Teachers have to promote their charm of personality continually to impel the students. This is the only way to improve the efficiency of the basic courses.

\section{Summary}

The theory and practice are two indispensable parts during the teaching process of the course "morality and law basis". It is not reasonable to emphasize one side while neglecting the other. The forming and development of good virtue and legal concept of college students is a complex process involving repeated recycling of inside-out and outside-in of morality and legal consciousness. Practice plays an important role in this process. The practice of the course includes several models like discussion, debating and field experience. The key of the process is to check whether the educated targets could take the morality and law basis into their minds and demonstrate the virtues and legal consciousness properly through theory learning and practice experiences. It is very necessary to emphasize field experience, feeling and value weighing during the whole process of teaching. The teachers' efforts are the vital part of improving the attraction and infectivity of college ideological and political theory courses. The courses can play an important role in the process of constructing socialist harmonious society. Therefore, we must strengthen and improve the new ways and new methods to do the college ideological and political work well.

\section{Acknowledgement}

This research was financially supported by CPC Beijing Municipal Education Committee Project Research on Teaching Model of Morality and Law in Vocational Colleges BJSZ2015ZC235 hosted by Guangmei Lin.

\section{References}

[1] Wei HONG, Youth Navigation. Scientific and Technical Documentation, Beijing, 2013

[2] Song J J. A study on participative teaching of the curriculum Morality and Law Basis in higher vocational and technical institutes[J]. Journal of Xinyang Agricultural College, 2012.

[3] Wang B Y, Jia S Y. On the Teaching of "Morality and Law Basisi"[J]. Journal of Tsinghua University, 2006.

[4] Chen H L, Lin W X. The Integration of Local Cultural Resources and the Course of "Ideological and Moral Cultivation and Legal Basis" in Higher Vocational College-Taking Chaoshan a district in Guangdong as an Example[J]. Journal of Guangdong Youth Vocational College, 2014. 